\title{
Katters predation på fåglar - ett alternativt sätt att beräkna antalet dödade fåglar
}

\section{Bird predation by cats-an alternative way to estimate the number of birds killed}

Hans Ryttman

Sveddvägen 13C, 75652 Uppsala, Sweden | hans.ryttman@telia.com

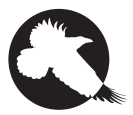

MANY STUDIES have tried to estimate the number of birds killed by cats, most of them based on the number of birds killed by a smaller number of cats in a local area and then scaled to larger areas, or a whole country. Such estimates can be confounded by several factors, and the results of one study may not always be applicable in another setting where climate, habitats, and societal structure differ. Here I used an alternative approach to estimate cat predation on birds using ring recoveries of birds reported to the Swedish national ringing scheme as killed by cats. With the assumption that ringed birds are taken by cats in an equal proportion as unringed birds, I estimate that about $0.03 \%$ of all passerine birds are killed by cats in Sweden annually. This amounts to about 100,000 birds per year, which is much lower than previous estimates.

Keywords: bird ringing | ring recoveries | passerines | Common Blackbird Turdus merula | Great Tit Parus major

\section{Introduktion}

Det är allmänt känt att katter tar fåglar, men att på ett bra sätt kvantifiera mängden tagna faglar har varit svårare att bestämma. De flesta studierna i ämnet har använt ett begränsat antal katter på ett litet område som bas för att beräkna antalet fåglar som tas per katt, och sedan ofta ställt det i relation till hur många katter det finns i ett land. Flera undersökningar har även gjorts genom att använda sig av studier gjorda i andra länder och direkt överföra dessa till sitt eget land (för en sammanfattning se Blancer 2013). I Sverige har mig veterligt endast två publicerade skattningar gjorts (Svensson 1996, Söderström 2016), men båda har utländskt mate- 
rial som utgångspunkt för beräkningarna. Enligt dessa båda skattningar skulle katterna i Sverige döda mellan 10 och 17,5 miljoner faglar per år.

Det finns enligt min mening många osäkerheter i de siffror som förts fram. Jag anser att skattningar från ett område där klimat, fågelfauna och samhällsstruktur skiljer sig från ett annat område i ett annat land inte går att jämföra. Andra faktorer som kan spela in när man vill jämföra studier är ålders-, köns- och individuella skillnader i katters beteenden, samt $i$ vilken grad de tillåts vara utomhus, men dessa faktorer är sällan redovisade. I Sverige redovisar t. ex. Statistiska centralbyrån (2012) att 56,8\% av katterna i "huvudsak vistades inomhus". Antalet katter som i huvudsak vistas utomhus, och vilken tid (tid på dygnet och årstid) de är ute, påverkar naturligtvis hur många fåglar de kan tänkas döda. Dessutom skattas ofta antal vildkatter med mycket stor osäkerhet i ett land och hur många fåglar dessa tar. Flera studier (se Blancer 2013) menar också att katter inte tar hem alla sina fångster och gör uppskattningar på hur många procent som katterna inte tar hem och "redovisar". Då både biotoper och tätheter av katter är ojämnt fördelade i ett land måste ett stratifierat urval göras. Enkätundersökningar har stora bortfall och risken för oärliga och av andra anledningar felaktiga svar är vanliga. Med tanke på alla de skilda variablerna som måste ingå i en väl genomförd statistisk studie anser jag att en korrekt statistisk undersökning inte är genomförbar i t. ex. Sverige. En möjlig alternativ metod skulle vara att utnyttja de uppgifter som ringmärkningen erbjuder.

\section{Metoder och resultat}

Staav (1996) har gått igenom Ringmärkningscentralens (RC:s) data från svensk ringmärkning och redogör för hur många fåglar som rapporterats som dödade eller troligen dödade av katt (vilka rapporteras med kod 610 respektive 611 i RC:s databas) av alla de som ringmärkts och återfunnits. Totalt var 936 individer av 85 arter rapporterade som dödade av katt under perioden 1974-1996 och av dessa fåglar var 94\% tättingar. Koltrast Turdus merula var den fågelart som oftast rapporterats dödad av katt, med 49 exemplar av de 43172 koltrastar (o,113\%) som ringmärkts under åren 1974-1996 (Staav 1996). Baserat på dessa data anser jag att detta är den maximala andelen som katter tar av svenska fåglar, då alla andra arter hade lägre procenttal än koltrast.

I följande beräkningar utgår jag från att ringmärkta fagglar tas lika ofta av katt som omärkta fåglar. Som också Staav (1996) påpekar kommer inte alla fåglar som tas av katt att rapporteras till $\mathrm{RC}$, och i vissa fall om de rapporterats omtalas inte heller om de är tagna av katt. Med tanke på kunskapsläget om ringmärkning i Sverige, och folks allmänna nyfikenhet, är min bedömning att de flesta som hittar en död ringmärkt faggel vill veta varifrån den kommer och därför rapporterar den, och att det fătal som inte rapporteras inte påverkar min skattning (se nedan).

Ett medeltal av proportionen "tagen av katt" för övriga 61 tättingarter som Staav redovisar är 0,03\%. Som exempel kan nämnas sädesärla Motacilla alba som ringmärktes i 46680 exemplar under perioden men där endast 11 rapporterats som tagen av katt (0,024\%), trots att arten ju ofta vistas på marken. Taltrast Turdus philomelos, som mer sällan vistas nära bebyggelse ( 53487 ringmärkta), rapporterades endast med 7 exemplar (0,013\%) och talgoxe Parus major, som onekligen är mycket vanlig nära bebyggelse och vid fagelmatningar, togs dubbelt så ofta som koltrast (97 exemplar) men där var ca fem gånger fler ringmärkta (254 634 exemplar, eller o,038\%). För antalet kattdödade icke-tättingar är antalet lågt, endast 48 av 299836 märkta under perioden (o,016 \%). För att säkerställa huruvida katter tar ringmärkta faglar lika ofta som omärkta borde experiment genomföras, men dylika är oetiska och kan aldrig vara berättigade. Den möjlighet jag kan tänka mig är att skatta antalet ringmärkta făglar av en art och sedan undersöka om de av Staav (1996) angiva procenttalen stämmer överens med de funna inskickade eller rapporterade ringmärka făglarna i dag. För att testa den prediktionen genomförde jag skattningar för koltrast respektive talgoxe.

\section{KOLTRAST}

Från den samlade svenska ringmärkningsdata rapporteras att $70 \%$ av ringmärkta koltrastar dör under det första levnadsåret (per 1 juli), och att överlevnaden därefter är ca $50 \%$ på årsbasis för adulta fåglar (Fransson \& Hall-Karlsson 2008). Varje år ringmärks i medeltal för tioårsperioden $2009-2018 \mathrm{ca} 2750$ flygga juvenila och adulta koltrastar. Därtill kommer 60-70 koltrastar som ringmärks som pulli, men dessa medräknar jag inte. Av de ringmärkta koltrastarna bör $3 / 5$ vara juvenila och $2 / 5$ adulta för att populationen ska vara konstant. 
Med det antagandet är 1650 exemplar juvenila och 1100 exemplar adulta. Antalet ringmärkta som överlever till kommande häckningssäsong är då $1650 \times 0,3+1100 \times$ $0,5=495+550=1050$ koltrastar. Summeras alla kohorter baserat på $50 \%$ överlevnad hos adulter blir antalet ringmärkta levande koltrastar ca 2100 . Under perioden 1974-1996 rapporterades i snitt två ringmärkta koltrastar per år som tagna av katt till RC, av de totalt ca 40 faglar rapporterade som tagna av katt per år i Sverige. Numera (2009-2018) rapporteras i medeltal 66 făglar till $\mathrm{RC}$ varje år (Thord Fransson i e-brev) med uppgiften "tagen eller troligen tagen av katt". Koltrastens numerär har ökat svagt men signifikant både då standardrutter och punktrutter inventerats (Green m. fl. 2019). Det är därför troligt att det skulle inkomma minst tre koltrastar som dödats av katt i dag då ringåterfynden har blivit $50 \%$ fler. Med tanke på att ringmärkning pågår under året kan katter ta någon koltrast till vilket gör att min skattning blir något $\mathrm{i}$ underkant.

\section{TALGOXE}

Som ett ytterligare exempel kan talgoxen tas. Baserat på ringmärkningsdata dör ca $75 \%$ av ringmärkta talgoxar under första levnadsåret (per 1 juli), under det andra levnadsåret dör $60 \%$ och åren därefter $50 \%$ per år (Fransson \& Hall-Karlsson 2008). Varje år ringmärks i medeltal för tioårsperioden 2009-2018 8750 pulli och 15400 juvenila och adulta talgoxar (Ringmärkningscentralen 2010-2019). Givet överlevnadsdata måste talgoxarna delas upp i $4 / 6$ juvenila och $2 / 6$ adulta för att erhålla en konstant populationsstorlek. Av de flygga talgoxarna är därför $2 / 3$ juvenila, eller ca 10300 exemplar, och 5100 adulta. Av de yngre talgoxarna finns därför $(8750+10300) \times 0,25=$ ca 4800 kvar och 2550 adulta. Av de yngre finns $4800 \times 0,4$ och av de äldre $2550 \times 0,5=$ ca $1900+$ ca $1300=3200$ talgoxar nästa år, och så vidare. Summeras kohorterna fås en summa om ca 13750 totalt antal ringmärkta talgoxar i landet varje år. Med den skattning som Staav (1996) anger för talgoxar som tas av katt $(0,038 \%)$ skulle drygt 5 talgoxar rapporteras varje år. Staav anger att ca 4 talgoxar togs av katt per år men med tanke på att talgoxens population ökat kraftigt (1,7-1,8 gånger sedan mitten av 1990-talet; Green m. fl. 2019) och tillkomsten av nya ringmärkta under året är min skattning något $\mathrm{i}$ underkant, liksom för koltrastar. De antal som jag har räknat fram ger alltså en underskattning av antalet koltrastar och talgoxar som katter tar. Men jag har bara räknat katternas predation på ett skattat antal ringmärkta fåglar och inte tagit hänsyn till ökningen om $50 \%$ av inlämnade/rapporterade ringar som kommer in till RC nu för tiden, eller de större populationerna som inventeringarna av både koltrast och talgoxe visar. Det är alltså troligt att antalet koltrastar och talgoxar som rapporteras tagna av katt är fler, men det skulle alltså krävas en genomgång av de ringar som de senaste åren har kommit in för att visa detta. Trots det högre förväntade antalet koltrastar och talgoxar som tas av katt idag, i jämförelse med Staavs rapporterade antal, så är inte den procentuella andelen högre. Dessa skattningar är inga bevis men ger en rimlighet $\mathrm{i}$ Staavs beräkningar och min tes att katter lika ofta dödar ringmärkta fagglar som omärkta.

\section{Diskussion}

Endast en ny undersökning som den Staav gjorde 1996 kan visa hur situationen mellan katter och faglar ser ut idag. Vissa arter, som vistas nära bebyggelse, som talgoxe, blåmes Cyanistes caeruleus och koltrast, har ökat i antal medan gråsparv Passer domesticus, stare Sturnus vulgaris och svartvit flugsnappare Ficedula hypoleuca har minskat (t. ex. Green m. fl. 2019). Kattantalet har ökat med $15 \%$ sedan Staav (1996) gjorde sin undersökning. Svensson (1996) nämner en miljon katter och i SCB:s undersökning från 2012 beräknas 1150000 katter finnas. Katters utomhusvistelse kan också ha förändrats, vilket naturligtvis påverkar katters möjligheter att ta fåglar. Även om ringåterfynden med beteckningen "tagen av katt" har ökat med drygt $50 \%$ och att vissa arter har ökat sina numerärer så anser jag att mina skattningar inte tyder på att Staavs uppgifter om katters predation på fåglar skulle ha ändrats sedan 1974-1996. Jag anser det därför osannolikt att kattpredationen skulle överskrida $0,1 \%$ (som för koltrast) då det gäller alla arter. Staav (1996) nämner också att 35\% av alla ringåterfynden med omständighet "tagen av katt" kommer från utlandet. Samtidigt bör det också finnas utländska ringar bland de kattdödade făglarna. Hur vanliga de är finns det inga uppgifter om.

Ottosson m. fl. (2012) anser att 70 miljoner par fåglar häckar i Sverige, vilket gör att man kan anta att det i Sverige i genomsnitt under ett år finns ca 300 miljoner fåglar. Om o,03\% av dessa togs av katt skulle katter ta ca 100000 fåglar per år. Detta är en betydligt 
lägre siffra än de som förut presenterats för svenska förhållanden. Alla undersökningar är behäftade med fel, så även denna studie. Exempelvis hittas inte alla kattdödade ringmärkta fåglar och katternas ägare skickar inte in ringen av någon anledning, vilket gör att antalet kattdödade fåglar förmodligen är större. Vildkatter finns åtminstone i södra Sverige och under den varmare delen av året. Vildkatterna tar ett okänt antal fåglar. Var och en må bilda sig en uppfattning om hur många fler kattdödade fåglar som tas i Sverige än de ca 100000 som kan räknas fram utifrån Staavs (1996) siffror från 1974-1996 och mina beräkningar med hans siffror som grund.

\section{Tack}

Tack till Ringmärkningscentralen för de lämnade uppgifterna och till de granskare vars värdefulla synpunkter har gjort uppsatsen bättre.

\section{Referenser}

Blancher P. 2013. Estimated number of birds killed by house cats (Felis catus) in Canada. Avian Conservation and Ecology 8: 3. https://doi. org/10.5751/ACE-00557-080203

Fransson T \& Hall-Karlsson S. 20o8. Svensk ringmärkningsatlas. Vol. 3. Naturhistoriska riksmuseet, Stockholm.

Green M, Haas F \& Lindström Å. 2019. Övervakning av fåglarnas populationsutveckling. Årsrapport för 2018. Rapport, Biologiska institutionen, Lunds universitet. 92 sidor. Tillgänglig från https:// bit.ly/3aYPa88.

Ottosson U, Ottvall R, Elmberg J, Green M, Gustafsson R, Haas F, Holmqvist N, Lindström Å, Nilsson L, Svensson M, Svensson S \& Tjernberg M. 2012. Fåglarna i Sverige - antal och förekomst. Sveriges Ornitologiska Förening, Halmstad.

Ringmärkningscentralen. 2010-2019. Antal ringmärkta och återfunna fåglar. Årsrapporter 2009-2018. Tillgängliga från https://bit. ly/3rUizHp.

Staav R. 1996. Katters fångst. Ringinform 19: 1-5.

Statistiska centralbyrån. 2012. Hundar, katter och andra sällskapsdjur 2012. Tillgänglig från https://bit.ly/2Ze5sVe.

Svensson S. 1996. Huskattens predation på fåglar i Sverige. [Predation on birds by the domestic cat in Sweden.] Ornis Svecica 6: 127-130. https://doi.org/10.34080/os.v6.22535

Söderström B. 2016. Hur tänker din katt? Bonnier Fakta, Stockholm. 222 sidor.

\section{English summary}

Several estimates on the number of birds killed by cats have been published, usually presented for a country, or a smaller region of a country. Blancer (2013) reviewed 15 different studies with estimates from USA, Great Britain, Switzerland and Canada. All these estimates used studies of cats from a smaller, restricted area, and the number of birds they delivered to their owners, followed by scaling of those results with the estimated number of house cats in the country. In some studies, the impact of feral cats was added, and their kills included in the totals. In my opinion, this approach is not directly transferable between countries because of differences in climate, the structure of the avifauna, urbanization, societal structures, etc. Furthermore, cats could show individual and age- and sex-related differences in bird hunting propensities, which can affect the estimate if the sample is small.

For Sweden, most data on cat predation comes from a paper by Staav (1996), where he counted the number of ringed birds killed by cats that were reported to the Swedish Bird Ringing Centre compared to the total number of ringed birds. Of birds killed by cats, $96 \%$ were passerines and in total $0.03 \%$ of the ringed birds were reported as taken by cats. The species most often killed by cats was the Common Blackbird Turdus merula, with $0.113 \%$ of ringed birds reported killed.

Here I use ring recovery data as an alternative method for assessing cat predation, with the assumption that ringed birds are taken equally often as unringed birds by cats. I start by estimating the number of ringed Common Blackbirds and Great Tits Parus major in Sweden, based on the average numbers ringed annually and the survival probabilities of different age classes. Using this method, I estimate that the number of ringed Common Blackbirds in Sweden are about 2,100. Staav (1996) found that $0.113 \%$ of ringed Common Blackbirds were killed by cats. When using this proportion, and comparing it to reported cases, a little more than two blackbirds ought to be reported as killed by cats annually, which is similar to the number Staav (1996) found. However, rings reported to the Swedish Bird Ringing Centre have increased by about $50 \%$ since the earlier study, and the Common Blackbird population has increased in Sweden. Therefore, I suppose that the 
Swedish Bird Ringing Centre receives reports of at least three ringed Common Blackbirds each year. Similar to Common Blackbirds, I estimated the number of ringed Great Tits in Sweden based on ringing totals and survival probabilities, and found about 13,750 ringed Great Tits to be present in the country. Staav (1996) found that $0.038 \%$ of the Great Tits are killed by cats. Using my estimated number of Great Tits, a little more than five would be reported annually as taken by cats, which is quite similar to the four Great Tits per year that Staav (1996) reported. The population size of Great Tits has increased and is $170-180 \%$ compared to the level of the previous study, which means that my figure might be underestimated.

If cat predation is unrelated to whether the bird is ringed or not it is possible to estimate the total number of birds killed by cats in the country. In Sweden Ottosson et al. (2012) reports an estimated 70 million pairs of birds (of all species) in the breeding population. However, this number changes over the seasons, both due to migration and due to mortality and reproduction. For my calculations I estimated that an average of 300 million birds are living in and passing through Sweden, which would lead to at least 90,00o birds being killed in Sweden by cats annually. This estimate is of course reliant on assumptions, such that ringed birds are delivered by the cat to its owner, that the owner reports the ring, and that the number of birds available for cat predation has been estimated correctly. Furthermore, I have not attempted to estimate predation by feral cats in Sweden, or how many birds migrating from other countries are caught by cats in Sweden. But given these restrictions, I believe is the estimated number of birds predated by cats should be in the order of 100,000 compared to earlier estimates of $10-17.5$ million birds per year in Sweden.

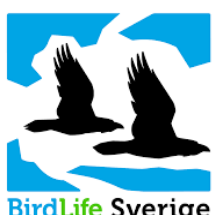

Ornis Svecica (ISSN 2003-2633) is an open access, peer-reviewed scientific journal published in English and Swedish by BirdLife Sweden. It covers all aspects of ornithology, and welcomes contributions from scientists as well as non-professional ornithologists. Accepted articles are published at no charge to the authors. Read papers or make a submission at os.birdlife.se.

Ornis Svecica (ISSN 2003-2633) är en fritt tillgänglig granskad vetenskaplig tidskrift som ges ut på svenska och engelska av BirdLife Sverige. Den täcker ornitologins alla områden och välkomnar bidrag från såväl forskare som icke-professionella ornitologer. Accepterade uppsatser publiceras utan kostnad för författarna. Läs uppsatser eller skicka in ditt bidrag på os.birdlife.se. 